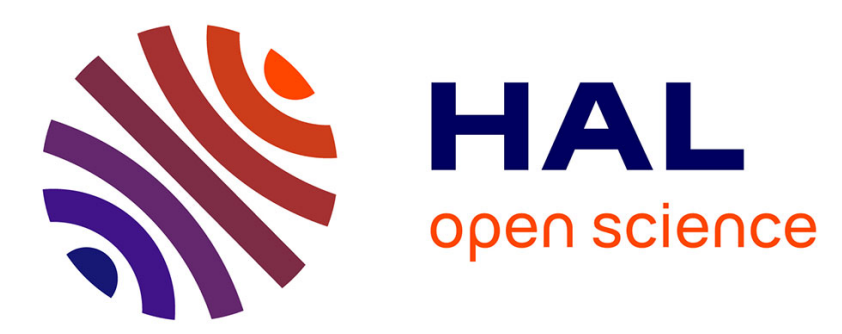

\title{
Who are the knowledge brokers in regional systems of innovation? A multi-actor network analysis
}

\author{
Martina Kauffeld-Monz, Michael Fritsch
}

\section{To cite this version:}

Martina Kauffeld-Monz, Michael Fritsch. Who are the knowledge brokers in regional systems of innovation? A multi-actor network analysis. Regional Studies, 2010, pp.1. 10.1080/00343401003713365 . hal-00605948

\section{HAL Id: hal-00605948 \\ https://hal.science/hal-00605948}

Submitted on 5 Jul 2011

HAL is a multi-disciplinary open access archive for the deposit and dissemination of scientific research documents, whether they are published or not. The documents may come from teaching and research institutions in France or abroad, or from public or private research centers.
L'archive ouverte pluridisciplinaire HAL, est destinée au dépôt et à la diffusion de documents scientifiques de niveau recherche, publiés ou non, émanant des établissements d'enseignement et de recherche français ou étrangers, des laboratoires publics ou privés. 


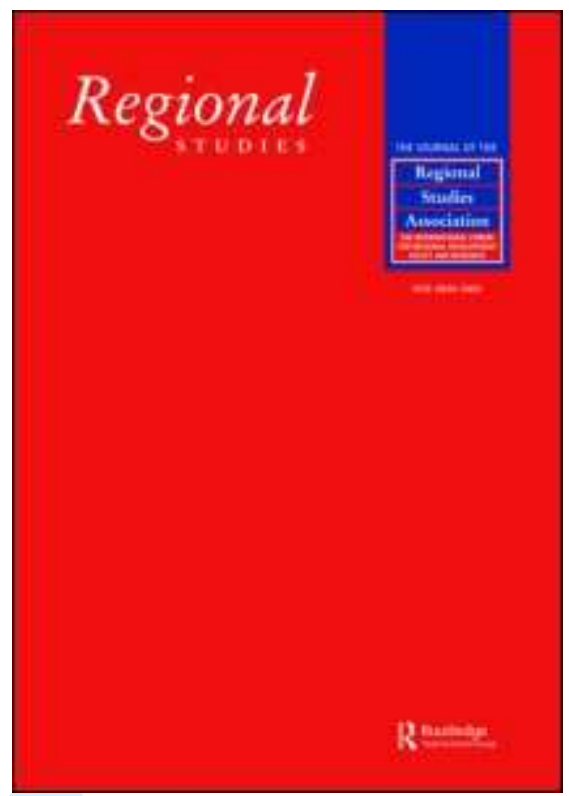

\section{Who are the knowledge brokers in regional systems of innovation? A multi-actor network analysis}

\begin{tabular}{|r|l|}
\hline Journal: & Regional Studies \\
\hline Manuscript ID: & CRES-2008-0303.R1 \\
\hline Manuscript Type: & Main Section \\
\hline JEL codes: & $\begin{array}{l}\text { D83 - Search|Learning|Information and Knowledge < D8 - } \\
\text { Information and Uncertainty < D - Microeconomics, D85 - Network } \\
\text { Formation < D8 - Information and Uncertainty < D - } \\
\text { Microeconomics, L14 - Transactional Relationships|Contracts and } \\
\text { Reputation|Networks < L1 - Market Structure, Firm Strategy, and } \\
\text { Market Performance < L Industrial Organization, O18 - Regional, } \\
\text { Urban, and Rural Analyses < O1 - Economic Development < O - } \\
\text { Economic Development, Technological Change, and Growth }\end{array}$ \\
\hline Keywords: & $\begin{array}{l}\text { regional systems of innovation, innovation networks, knowledge } \\
\text { exchange, knowledge broker, gatekeeper }\end{array}$ \\
\hline
\end{tabular}

\section{S ScholaroNE \\ Manuscript Central}




\title{
Who are the Knowledge Brokers in Regional Systems of Innovation?
}

\author{
A multi-actor Network Analysis \\ MARTINA KAUFFELD-MONZ* and MICHAEL FRITSCH $†$ \\ * Institute for Urban Research and Structural Policy (IfS) Berlin, Lützowstr. 93, D-10785 Berlin, \\ Germany. Email: kauffeld-monz@ifsberlin.de; kauffeld-monz@freenet.de \\ $\dagger$ School of Economics and Business Administration, Friedrich Schiller University Jena, \\ Carl-Zeiss-Str. 3, D-07743 Jena; and German Institute for Economic Research (DIW Berlin); and Max \\ Planck Institute for Economics, Jena, Germany. Email: m.fritsch@uni-jena.de
}

(Received November 2008: in revised form December 2009) 


\section{KAUFFELD-MONZ M. and FRITSCH M.}

Who are the knowledge brokers in regional systems of innovation? Regional Studies. The discussion on regional innovation systems emphasizes the duality of local and global links. Our empirical analysis of 18 German regional innovation networks shows that public research organizations, especially universities, are profoundly involved in knowledge exchange processes and possess more central (broker) positions within their regional innovation networks than private firms. This results, in part, from public research's "gatekeeper function" which can be particularly important in lagging regions that typically suffer from a lack of large firms which often fill this role in advanced regions. The transferred knowledge is absorbed, especially, by private firms without inter-regional R\&D cooperation activity.

Regional innovation systems, innovation networks, network analysis, knowledge broker, gatekeeper

\section{KAUFFELD-MONZ M. und FRITSCH M.}

Wer sind die Wissensbroker in regionalen Innovationssystemen? Regional Studies. Der Ansatz der regionalen Innovationssysteme betont die Bedeutung der Dualität globaler und lokaler Austauschbeziehungen für Innovationsprozesse. Unsere empirische Analyse von 18 regionalen Innovationsnetzwerken in Deutschland zeigt, dass öffentliche Forschungseinrichtungen - insbesondere Universitäten - intensiv in die Wissensaustauschprozesse dieser Netzwerke involviert sind und mehr zentrale (Wissensvermittler-)Positionen einnehmen als die in den untersuchten Netzwerken vertretenen Unternehmen. Dies resultiert zum Teil daraus, dass die öffentliche Forschung in Regionen mit Entwicklungsrückstand eine "Gatekeeper-Funktion" wahrnimmt, welche in besser entwickelten Regionen typischerweise größeren Unternehmen zukommt. Das in das Netzwerk eingespeiste Wissen wird insbesondere von denjenigen Unternehmen absorbiert, die über keine eigenen regionsexternen FuEPartnerschaften verfügen.

Regionale Innovationssysteme, Innovationsnetzwerke, Netzwerkanalyse, Wissenstransfer, Gatekeeper

JEL classification: $\quad$ D83, D85, L14, 018 


\section{INTRODUCTION}

The concept of innovation systems emphasizes that innovation processes are characterized by a pronounced division of labor. Hence, effective linkages between the knowledge generating, the knowledge transferring, and the knowledge exploiting components of a system are of key importance for the respective innovation processes. Empirical research has shown that regional networks of co-operative relationships can play a crucial role in the division of innovative labor by fostering personal fact-to-face contacts that facilitate the exchange of uncodified knowledge (LONGHI, 1999; DAHL and PEDERSEN, 2004). Moreover, regional network structures can accelerate trust building within R\&D collaborations that typically require the mutual disclosure of competition relevant knowledge (NOOTEBOOM, 2003; DAS and TENG, 2001). These advantages of regional networks are regarded as one of the main causes of localized knowledge spillovers (AUDRETSCH and FELDMAN, 1996; BRESCHI and LISSONI, 2001). Regional networks and localized knowledge spillovers may explain why knowledge diffusion is concentrated close to the locus of knowledge generation but also why innovation activity is found to be clustering in space (AUDRETSCH and FELDMAN, 1996; OERLEMANS et al., 2001; MALMBERG and MASKELL, 2002; FELDMAN, 1994). Due to this high importance of the geographic dimension for innovation processes regional systems of innovation have become an important unit of analysis (COOKE, HEIDENREICH and BRACZYK, 2004).

Regional innovation networks may not only promote knowledge flows that are based on direct relations, but they can also contribute to knowledge diffusion by indirect links resulting from brokerage. Brokers are actors in the network that transfer knowledge between organizations that are not linked directly (NOOTEBOOM, 2003). Such an indirect transfer may also involve a transformation of the respective knowledge. Moreover, brokers have the opportunity to derive their own benefits from their intermediary position by re- 
combining and exploiting knowledge that they draw from various contexts (HARGADON and SUTTON, 1997).

Whereas trust based local network relations most notably are conducive to the effectiveness of knowledge exchanges, global links may provide the regional innovation system with knowledge that differs from its inherent knowledge base. Thus, being connected to 'global pipelines' is regarded very important for the acquisition of innovation related knowledge in a region (CAMAGNI, 1991). Since many of the small firms due to their limited resources lack such an access to global knowledge sources larger firms in a region may assume the role of a "knowledge broker" and "gatekeeper of knowledge" by supplying the network organizations with knowledge they have attained over the course of their global exchange processes (MORRISON, 2008; LAZERSON and LORENZONI, 1999; BIGGIERO, 2002; AGRAWAL and COCKBURN, 2003; MUNARI et al., 2005). However, in lagging regions such large and globally linked firms are often under-represented or even entirely missing. This gives rise to the question about the possibilities to compensate for this deficit. One may particularly ask in this respect to what extent public research organizations may fill this gap, i.e. provide access to global knowledge sources and act as knowledge gatekeepers in regional innovation networks (FRITSCH and SCHWIRTEN, 1999; VARGA, 2000)?

Our study focuses on knowledge exchange processes that took place in 18 regional networks of innovation. The organizations involved in these networks collaborated in R\&D over a period of at least five years. All regions in our study can be characterized as lagging according to the criteria applied by the European Cohesion Policy. These regions especially lack intensively innovating large firms. We try to identify central groups of organizations with regard to knowledge exchanges within the networks. The investigation involves 


\section{THE RELATION BETWEEN LOCAL AND GLOBAL KNOWLEDGE SOURCING 2.1 THE IMPORTANCE OF LOCAL LINKS AND EMBEDDEDNESS FOR INNOVA- TION}

In knowledge intensive economies, innovation is considered as a key driver for economic development. Several studies on localized spillovers highlight the pronounced regional dimension of innovation processes (FELDMAN, 1994; JAFFE et al., 1993). A main reason for such localization of innovation processes discussed in the literature is the benefit of spatial proximity that involves the possibility of frequent face-to-face contacts. This type of contact fosters multi-dimensional communication (verbal, physical, context specific, non-intentional) that is essential for trust building and for the transfer of complex and uncodified knowledge (STORPER and VENABLES, 2004). Generally, processes such as the constitution of new co-operative relationships, periodically arising coordination requirements, the discussion of ill-defined problems, re-evaluation of projects as well as strengthening of social ties may be more effective if they are based on direct personal contacts (FONTES, 2005). Spatial proximity is not only conducive to dyadic exchange relations, but it may also foster collective learning processes (CAPELLO, 1999; BOSCHMA and LAMBOOY, 1999; LAWSON and LORENZ, 1999) and may permit higher flexibility concerning the pooling and bundling of resources (SABEL, 1989). In this respect, relations that are embedded in institutional arrangements such as regional innovation networks can 
be considered as a precondition of effective and successful regional systems of innovation (COOKE et al., 2004).

The scope and intensity of personal relations within a dynamic regional innovation system is the basis for the emergence of "local buzz" (STORPER and VENABLES, 2004; BATHELT et al., 2004). This term refers to the idea that in a specific dynamic milieu, many processes that entail rich information and inspiration do emerge simultaneously (BATHELT et al., 2004). Local buzz refers to the co-localization of individuals and firms within the same industry and corresponds to Marshall's "industrial atmosphere" (MARSHALL, 1927). Local buzz is generated by specific information and their continuous update, by intended as well as unintended learning processes as the result of purposeful and casual meetings, by similar patterns of interpretation as well as by shared cultural traditions and industry specific practices (BATHELT et al., 2004).

The organizations involved in a regional network do not only benefit from local buzz, but they also contribute to its emergence. Local buzz, however, does not come about without specific investments. The development of robust inter-organizational relations for innovation, the establishment and maintenance of customer-supplier relations, the participation in networks and numerous discussions require time and resources. Thus, the existence of local buzz, although spontaneous and fluent by nature (BATHELT et al., 2004), does not only result from the mere co-location of individuals and organizations, but it is based on their active participation in networking (CROWLEY, 2007). This may explain why knowledge does not diffuse evenly within a region but rather diffuses within a core group of actors that are characterized by high absorptive capacities (GIULIANI and BELL, 2005). Several studies that apply different methodical approaches confirm this finding by identifying co-operations between public research institutions and private firms as a crucial 
factor in the operation of regional innovation systems (BRESCHI and LISSONI, 2001; AGRAWAL and COCKBURN, 2003; FRITSCH, 2004; FRITSCH and SLAVTCHEV, 2007; VAN LOOY et al., 2003; WATERS and LAWTON-SMITH, 2002).

\subsection{THE PROBLEM OF LOCK-IN}

Besides the advantages of socially embedded relations such as regional innovation networks, embeddedness may also lead to severe problems (LAZERSON and LORENZONI, 1999; MERTON, 1936). One particular problem is the danger of a regional lock-in situation that may result in technologically inferior solutions (GRABHER, 1993; BOSCHMA, 2005; GLASMEIER, 1994). When everyone in a network is applying the same routines and is exposed to the same ideas, the opportunity to learn from each other is rather limited (NELSON and WINTER, 1982). Furthermore, intensive regional network relations involve the danger of producing "blind spots" in terms of insufficient attention being paid to the strategies and competences of competitors external to the region (POUDER and ST. JOHN, 1996). Thus, local networking and knowledge accumulation can lock the local actors in obsolete, non-competitive technological trajectories (CAPELLO, 1999; DOSI, 1982; CAMAGNI, 1995). Especially highly specialized regions (GRAF, 2007) and technologies with a pronounced international orientation such as biotechnology (GERTLER and LEVITTE, 2005) are faced with this risk and require intensive transfers of knowledge and information across regional borders. Therefore, it is argued that successful innovation is based on the appropriation of specialized regional know-how, on the one hand, and globally dispersed knowledge, on the other hand (BATHELT et al., 2004). A global orientation typically is found with innovation intensive firms in advanced stages of development (GEENHUIZEN, 2007). These findings correspond to the industry-life-cycle and the cluster-life-cycle-hypothesis, suggesting that economic activity is more geographically dispersed as the industries mature (SWANN, 1998; AUDRETSCH and FELDMAN, 1996). 
All these arguments and observations suggest that inter-regional flows of information and knowledge are important for regional innovation processes (CAMAGNI, 1991). Especially they are advantageous if they are appropriately linked to local buzz (BATHELT et al., 2004; SCOTT, 1996; ASHEIM and ISAKEN, 2002). The simultaneous exploitation of local and global knowledge sources requires adequate interfaces between the local and the global sphere (GRAF, 2007; KIM and TUNZELMANN, 1998). However, the identification of global knowledge sources as well as development and maintenance of global contacts involve considerable financial and personal capacities, which often are not available in small- and medium-sized firms (SMEs) (FONTES, 2005; GRABHER, 2002; LINDHOLM-DAHLSTRAND, 1999). This leads to the question how such firms can attain essential knowledge that is not available within their region?

We suppose that many SMEs obtain access to external knowledge by connecting to regional innovation networks that include actors that are well linked to global knowledge sources. Such "gatekeepers" (ALLEN, 1977) or "boundary spanners" (SAPSED et al., 2007) play an important role in regional systems of innovation as they absorb globally dispersed knowledge and introduce it to regional innovation processes (BATHELT et al., 2004). The functions of the gatekeepers are to monitor the external environment and translate the technical information into a form that is understandable to the local organizations (COHEN and LEVINTHAL, 1990). Thus, gatekeepers help to extend the regional scope of new ideas (WINK, 2008). As a result, the gatekeepers can make a considerable contribution to the acquisition, generation, and diffusion of knowledge (GIULIANI and BELL, 2005). They may also compensate for structural deficits of new industries, which in their early stages of development are often faced with institutional weaknesses (HOWELLS, 2006; CARLSSON, 1994). Hence, gatekeepers can be regarded as a precondition for an appropriate performance of organizations (CROSS et al., 2002). ${ }^{1}$ 
Large firms are often found to fulfill the role of a gatekeeper because of their interregional orientation, which includes international contacts and rich expertise (LAZERSON and LORENZONI, 1999; BIGGIERO, 2002; MUNARI et al., 2005; BOARI and LIPPARINI, 1999; ALBINO et al., 1999). Their knowledge may be transferred to local SMEs particularly by involving them in R\&D projects. Through co-operation with large firms, SMEs can be connected to basic research and may gain access to large firms' distribution channels (KNORRINGA, 1996). A number of studies conclude that especially multinational enterprises' access to "global pipelines" is of crucial importance for a local economy (BIGGIERO, 2002; VEUGELERS and CASSIMAN, 1999). Thus, large firms are important elements within regional innovation networks because they convey globally dispersed knowledge into their regional network of customers and suppliers (MORRISON, 2008).

\section{RESEARCH DESIGN}

\subsection{GENERAL APPROACH}

Lagging regions tend to be characterized by a relatively high share of SMEs; thus, larger firms that could act as gatekeepers of knowledge are rare or completely missing (FONTES, 2005). This study investigates in how far public research organizations can compensate for this deficit. From patent data analyses, we know that there are often many links between public research organizations and firms that possibly involve knowledge flows (CANTNER and GRAF, 2006; GRAF and HENNING 2009). The effectiveness of a gatekeeper function within regional innovation networks is based on the following preconditions:

- The gatekeeper organization is well linked to global knowledge sources as well as to local organizations (MUNARI et al., 2005; GIULIANI, 2005). 
- The gatekeeper organization holds high absorptive capacities in the relevant knowledge domains and has adequate capacities to accumulate and store this knowledge (LAZERSON and LORENZONI, 1999; MUNARI et al., 2005; GRAF, 2007).

- The gatekeeper possesses the capacity, the ability, and is willing (incentive structure) to transfer his knowledge into the region and to share it with local partners (CRANEFIELD and YOONG, 2007; HARADA, 2003).

We suppose that public research organizations cope with these requirements in many respects. Public research organizations possess a large stock of R\&D personnel and have access to globally dispersed knowledge as the scientific community tends to be well connected internationally. Moreover, most if not all public research organizations have a knowledge transfer mission and are characterized by an "open science mentality" and many of them are also familiar with knowledge transfer due to their teaching activity. Hence, public research organizations are principally qualified to fulfill a gatekeeper function (GRAF, 2007; OWEN-SMITH and POWELL, 2004). In contrast to the public research organizations' open science mentality, private firms often share their knowledge only with a strictly selected group of closely connected partners (MORRISON, 2008). As a result, the diffusion of their knowledge tends to be rather restricted. The differences between public research organizations and for-profit organizations mainly stem from a sharply divergent selection environment (OWEN-SMITH and POWELL, 2004) and their disparate approaches to the dissemination and use of scientific findings (DASGUPTA and DAVID, 1987; DASGUPTA and DAVID, 1994) that makes new knowledge flowing out of universities more readily available than the knowledge from commercial organizations is (JAFFE et al., 1993; OWEN-SMITH and POWELL, 2004). 
There may be a number of impediments for transfer of knowledge and technology from public research to private businesses such as information deficits and problems of access, technological mismatches, restricted absorptive capacities of the firms as well as considerable requirements of further investments due to the proof-of-concept stage of academic (SCHMOCH et al., 2000; HALL et al., 2001; HARPER and RAINER, 2000; SCHMOCH, 1999; FRANZONI and LISSONI, 2008)inventions (HALL et al., 2001; HARPER and RAINER, 2000; SCHMOCH, 1999; FRANZONI and LISSONI, 2008) (SCHMOCH et al., 2000; HALL et al., 2001; HARPER and RAINER, 2000; SCHMOCH, 1999; FRANZONI and LISSONI, 2008). Such problems can, however, be considerably reduced if public research organizations and private firms are connected within a regional innovation network.

Since the gatekeeper function includes the more general characteristics of acting as a knowledge broker (with the exception of the linkages to global knowledge sources), our empirical analysis will first focus on brokerages before investigating who the gatekeepers are and how they fulfill their function in the innovation networks under study.

\subsection{HYPOTHESES}

We suppose that public research organizations transfer a considerable amount of knowledge to their network partners (hypothesis 1). For this reason, they can be regarded as a central group in innovation networks (hypothesis 2). This prominent position with regard to knowledge transfer is closely related to the network centrality of public research organizations, which results in the exertion of broker positions. A broker position emerges if an organization links two other organizations that are not directly connected. 
The benefits resulting from brokerage may be diverse. Among these benefits is reduction of problems caused by information asymmetry that may result from mediating agents (NOOTEBOOM, 2003). Brokers may act as arbitrators of contracts and can help to prevent misunderstandings (BURT, 2005). A broker with a good reputation within the network may help to control the risk of involuntary spillovers and mediate the building and maintenance of trust (NOOTEBOOM, 2003; ZUCKER, 1986; SHAPIRO, 1987). Clearly, broker positions may entail benefits for the brokering organization as well as for organizations that are linked to the broker. Thus, we expect social returns (brokers generate additional knowledge transfer to their network partners) as well as private benefits (brokers acquire additional knowledge) resulting from brokerage (hypothesis 3). To a certain degree, private and social benefits may occur independently: Private benefits of brokering organizations result from application of knowledge absorbed from different network partners and contexts (HARGADON and SUTTON, 1997). Social benefits arise from the knowledge that brokers are passing through from one organization to another. Public research organizations are not only regarded important interfaces in respect to knowledge exchange within a network. Compared to small firms, public research organizations also possess better access to global knowledge sources (hypothesis 4). This may result in additional transfer of such knowledge to network partners, i.e. the fulfillment of a gatekeeper function (hypothesis 5).

\subsection{DATA AND MEASUREMENT}

\subsubsection{DATA}

Our analysis is based on detailed information about 18 East German regional innovation networks that were initiated in 1999. The networks were selected in the promotion policy program "InnoRegio", which aimed to improve regional innovation systems in lagging regions (see Eickelpasch and Fritsch 2005 for details about this program). The InnoRegio program tried to stimulate the formation of innovative networks that involved private firms 
as well as public research organizations (EICKELPASCH and FRITSCH, 2005; EICKELPASCH et al., 2002a; EICKELPASCH et al., 2002b; BMBF, 2005). The networks under study show a number of common features that result from the guidelines and conditions of the policy program. Since one of these conditions was that most of the organizations belonging to the network had to be located in spatial proximity, the distances between partners tend to be rather small with a maximum of about 50 kilometers. $^{2}$ The regions involved suffer from similar disadvantages such as low income and productivity, lack of larger firms, etc. that are mainly a result of the transformation process in East Germany, the former German Democratic Republic (GDR) (KRONTHALER, 2005). For these reasons, the networks should be highly comparable. Differences between the networks particularly concern industries and technologies ${ }^{3}$ involved as well as the number and the character of organizations. Our analysis involves 338 different organizations that belong to one of the 18 networks under study. ${ }^{4}$ About 60 percent of these organizations were private firms. Universities consist of 10 percent of the total, and about 16 percent were public or private non-university research institutes. ${ }^{5}$

About 20 percent of the organizations involved in the networks were vertically linked by buyer-supplier relations. Most of the network-firms are small or medium-sized: 50 percent have less than 20 employees and only 10 percent have more than 100 employees. The service sector firms, which contribute to about 40 percent of the private firms in the networks, are mainly engaged in engineering services and in R\&D. The manufacturing firms include a high proportion of mechanical engineering, medical engineering, measurement engineering, and control technology as well as textiles (EICKELPASCH et al. 2002b). The firms in the selected networks exhibit an above average performance with regard to $\mathrm{R} \& \mathrm{D}$, the introduction of new products on the market, and they consider themselves to be more competitive than most of the other suppliers in the respective market 
(EICKELPASCH et al. 2002b). For this reason, there is a certain sample selection bias with regard to innovation attitudes, innovative capabilities as well as expectations about future growth.

\subsubsection{NETWORK CONSTRUCTION AND NETWORK MEASURES}

The data were gathered by postal questionnaires in the year 2004 that resulted in a rather high response rate of about 80 percent. For network construction, each participant was asked to name his most important partner(s) within the network. On average, three network members were named, in most cases partners of actual R\&D projects. ${ }^{6}$ Organizations that participated in a network but did not respond the questionnaire have been included in the analysis if at least two of the responding actors named the non-responding organization as one of their "most important partners". In this manner, we tried to capture the complete network. ${ }^{7}$ On the basis of these links, we generated a network matrix for each network. We assume that knowledge and information is exchanged along these links. ${ }^{8}$ Altogether, the network-members named 338 organizations that can be attributed to 18 different regional networks of innovation. As an example, figure 1 shows a network graph for one of the innovation networks in our sample. This network consists of 54 actors (individuals), and they have been attributed to 32 different organizations. Three of the actors can be regarded isolates because they neither named partners, nor were they named by other actors as most important partner. Thus, we had to exclude them from the network analysis that was finally conducted on the basis of 29 organizations (nodes).

For each of the 18 networks, we calculated several measures that indicate centrality of an organization and are supposed to be positively correlated with information and knowledge exchange. These measures are: 
- Degree: The number of an organizations' direct links of knowledge transfer to other organizations in its network. Often the number of degrees is considered to be an indicator of prestige (JANSEN, 1999). An organizations' direct links as a whole are called "ego network";

- Betweenness is a distance-based centrality measure. It describes an essential feature of innovation networks. Unlike degree-based measures, distance-based centrality measures include indirect links within the network. Betweenness reports the frequency an organization (i) is located on the ,shortest path“ (geodesic distance) of two other organizations (jk) that are not linked directly. Betweenness may indicate an organizations' ability to absorb information (OWEN-SMITH and POWELL, 2004) that can be transferred to network partners.

- Broker: In contrast to betweenness, only direct links of an organization (its ego network) are included for calculating the broker measure. A broker position arises if an organization links two organizations of its ego network that are not connected directly. In such a case, the brokering organization may act as a connector of different contexts. This measure is the number of organizations in the ego network of an actor that are indirectly linked by this actor. ${ }^{9}$ While betweenness may indicate an organizations' ability to absorb and transfer information, the broker measure may be more suitable for indicating knowledge flows. Unlike information, knowledge hardly passes a great number of nodes (organizations) that are not linked directly because knowledge is more complex than information and often involves tacit components. ${ }^{10}$ By applying the broker measure, we suppose that knowledge can be passed via at least one interface (the broker).

The data include indicators for transfer and absorption of both information and knowledge. The extent of transfer as well as absorption has been measured on a 5-point 
Likert scale ranging from "very few" to "very much" (table 1 in Appendix). With regard to different types and dimensions of knowledge (NONAKA, 1991; COWAN et al., 2000), our analysis focuses mainly on technological know-how exchanged between the organizations, measured by "the extent of technological support" provided to or received from network partners (table 1 in Appendix). However, there may also be some degree of "know-what" (declaratory/factual knowledge) as well as "know-why" (scientific knowledge) included in the exchanges. We have strong indication from in-depth interviews with selected network members that a considerable part of the knowledge exchanged is of a tacit nature.

Our analysis of gatekeeper effects is based on information about existence as well as frequency of inter-regional $R \& D$ cooperation in basic research, product innovation, and process innovation (measured on a 5-point Likert scale ranging from "not at all" to "very often"; table 1 in Appendix). Moreover, the data allow for running analyses by different organization types that represent fundamental elements in the regional innovation system approach: Universities, non-university PROs (non-university PROs), private research organizations, manufacturing firms, and service firms.

\section{EMPIRICAL RESULTS}

\subsection{KNOWLEDGE TRANSFER OF PUBLIC RESEARCH}

Our results point to a prominent role of public research (universities and non-university PROs) with respect to knowledge exchange within the networks under study as stated by hypothesis 1 . This can be illustrated by a network graph for one of the networks under study (figure 1). Based on a 5-point Likert scale (table 1 in Appendix), we found that the knowledge transfer of public research organizations within this network amounts to 4.1, whereas private firms show a significantly lower value of 3.2 (statistically significant at the 5-percent level; Mann-Whitney-Test). ${ }^{11}$ 
- insert "Figure1: Knowledge transfer within one of the networks studied" about here -

The network we pictured in figure 1 is more a typical than a special case with respect to the results for the whole sample (figure 2). However, we have convincing evidence that public research organizations by no means can be considered as a homogeneous group regarding knowledge exchange: The universities are the group of actors that on average transfer the highest amounts of knowledge to their network partners, closely followed by the service firms. Similarly, they gain considerable benefits in terms of knowledge absorption from network partners. However, non-university PROs we found to be poorly involved into exchange processes of their regional networks. ${ }^{12}$ Thus, as a type of organization they cannot be regarded as a central source of knowledge. The relatively intense participation of the universities in the transmission as well as in the absorption of knowledge strongly indicates that the respective innovation processes were not linear in character but that there are pronounced feedback-loops as proposed by the chain-linked model of innovation processes. Hence, our hypothesis 1 is confirmed with respect to the universities at least.

- insert "Figure 2: $\quad$ Transfer and absorption of knowledge by organization types" about here - 


\subsection{CENTRALITY OF PUBLIC RESEARCH ORGANIZATIONS: DEGREE AND BETWEENNESS}

As outlined above (section 3.3.2), an organizations' centrality within a network can be measured by several indicators. We found strong evidence that public research organizations hold a more central position in the networks than the private sector firms due to their "degree" and "betweenness": While public research organizations maintain about 4.5 direct partnerships (so-called degree) within their regional innovation network, the private sector firms reported to maintain on average 2.9 such relationships (significant at the 1percent level; Mann-Whitney-Test). Certainly, this indicates resource restrictions of SME. The "normalized degree centrality"13 shows that private firms on average are linked with 14 percent of the network organizations, whereas public research organizations are linked with 25 percent of those.

Due to resource restrictions, actors can maintain only a limited number of direct ties (partnerships) at a certain point of time. One of the fundamental advantages of networks is considered in the potential of additional indirect links whose connection by intermediaries allows the transmission of information and knowledge. Distance-based network measures like "betweenness centrality" account for such indirect links. The betweenness measure indicates how often an organization (i) is located at the „shortest path“ (so-called geodesic distance) of two other organizations (jk) that are not linked directly. It is evident that public research organizations show a significantly higher normalized betweenness centrality (11.1) than the firms (2.9). ${ }^{14}$ In other words: While the private firms are located on nearly 3 percent of all "shortest paths" in their network, the public research organizations are on about 11 percent of them. Such positions are seen as a specific feature of innovation networks. Betweenness centrality is supposed to indicate an organizations' possibility to absorb information from network partners and to transfer it to others. Indeed, we found be- 
tweenness positively related to the transfer of information to network partners. However, this relationship is statistically significant only with respect to the private firms, not for the public research organizations. ${ }^{15}$ Since there is strong evidence that the universities are highly involved in the information transfer as well (FRITSCH and KAUFFELD-MONZ, 2010), we suspect that the statistical insignificance of the relationship between universities' betweenness and the transfer of information to their network partners may be due to the relatively small number of entities in our analysis (35 universities). Remarkably, we find no indication in our data for a relationship of the betweenness and the absorption of information. Obviously, the information that has been transferred was passed through to network partners rather than being applied directly within their own organizations.

\subsection{BROKER POSITIONS AND KNOWLEDGE EXCHANGE}

The broker measure is limited to direct links of an organization, the ego network. A broker position emerges if an organization (i) links itself to other organizations (jk) of its ego network that are not connected directly. The broker organization, therefore, is an immediate neighbor in the network. This permits transmission of complex and personal knowledge that is usually restricted to direct exchanges between organizations (jk). However, a broker organization may also re-combine the knowledge it acquires from different network partners and can, in this way, generate new knowledge.

First, we calculated the number of broker positions for each organization. ${ }^{16}$ In the network that is shown in figure 3 , a university holds an outstanding central position (upwards-facing triangle in the middle of the graph). Because the partner-organizations of the universities' ego network are not well connected with each other, the university has a huge number of broker positions (367). Furthermore, two non-university PROs (downwardsfacing triangles) hold central positions and show a considerable number ( 7 each) of broker 
positions. A large number of firms (circles) are without any broker position. The largest number of broker positions that a firm holds in this network is 3. According to our data, a typical broker firm is characterized by a relatively large firm size and high R\&D capacities. Additionally, it has maintained co-operative relationships with several of the network partners before the InnoRegio program was established. Unlike firms that do not assume a broker position in their network, the typical broker firm has relatively little concerns with regard to unintended knowledge spillovers: While 12 percent of the manufacturing firms without broker positions do not patent because they fear that this could jeopardize their knowledge advantage, only 6 percent of the manufacturing firms with broker positions state that this prevents them from patenting. ${ }^{17}$

-insert "Figure 3: Number of broker positions" about here -

The results for the whole sample (18 networks) indicate that 80 percent of the universities, and 67 percent of non-university PROs have at least one broker position (table 1). For the manufacturing firms, this share is 56 percent and for the service firms it is 81 percent. Moreover, we found differences between these different groups of actors concerning the number of broker positions per organization: Universities hold on average 22.15 broker positions, non-university PROs hold 5.65, manufacturing firms hold 2.6, and service firms have 4.0 broker positions (table 1). This means that especially the ego networks of the universities $^{18}$ are rife with organizations that are not (well) linked with each other. Altogether, these findings confirm the central position of public research organizations, especially of the universities, in the regional innovation networks under investigation (hypothesis 2).

- insert Table 1 about here: Broker positions and their relation to knowledge exchange ${ }^{19}$ - 
Because the network approach implies that information and knowledge flow not only results from direct ties, but also from indirect links that expand the access to knowledge sources we suppose broker positions to be positively related to knowledge exchange. But broker positions only result in broker functions if the broker finally conveys knowledge from one organization and context to another (SAPSED et al., 2007). With respect to universities and manufacturing firms, the mean values as well as the results of nonparametric tests show (at the 5-percent level; Mann-Whitney-Test) that the existence of at least one broker position has a positive effect on the extent of knowledge absorbed and on the extent of knowledge that is transferred to network partners (table 1, rows 1 and 5). Apparently, universities' and manufacturing firms' broker positions result in a broker function. Thus, universities as well as manufacturing firms are able to draw private benefits in terms of higher levels of knowledge absorption due to a broker position, and they also generate social benefits in terms of a higher level of knowledge transferred to network partners. ${ }^{20}$ With respect to non-university PROs, we found no significant relationship between their amount of knowledge transfer to network partners and existence of a broker position (table 1, row 7).

In a further step of analysis, we also examined the relation between the number of broker positions that an organization assumes in its network and its extent of knowledge exchange with network partners (table 1). The respective correlation coefficients (table 1, row 6) indicate that universities transfer significantly more knowledge to their partners as their number of broker positions increases. The same is true for the manufacturing firms in our sample (table 1, row 2). Unlike the mere existence of a broker position, the increasing number of broker positions does not seem to be positively related with knowledge absorption for these two types of organizations (table 1, column 4, rows 2 and 6): The correlations suggest that rising number of broker positions does not result in private benefits in 
terms of increasing knowledge absorption but in social benefits that emerge through additional knowledge transfer to network partners. Concerning service firms as well as nonuniversity PROs, the number of broker positions appears to be unimportant for their extent of knowledge exchange (table 1, rows 4 and 8). Thus, we get mixed results concerning our hypothesis 3: Only manufacturing firms' and universities' broker positions result in a broker function. An increasing number of broker positions turns out to be conducive to the extent of knowledge they transferred to network partners (social benefits) but does not enhance their knowledge absorption (no private returns).

\subsection{The gatekeeper function}

As outlined above (section 3.1), a gatekeeper function requires regional embeddedness as well as access to inter-regional knowledge sources. Especially cooperative partnerships are regarded as effective means to gain access to personal knowledge that is not ubiquitously available because of limited personal mobility. Therefore, our investigation of the gatekeeper function is based on information about the inter-regional R\&D cooperation activity of the actors in the fields of basic research, product innovation, and process innovation that was raised in the questionnaires.

- insert "Table 2: Regional and inter-regional cooperation activity by organization types (in $\%) "$ about here -

Public research organizations show a pronounced propensity for inter-regional cooperation with respect to all three categories of innovation activity in our data (table 2). On average, public research actors exhibit a higher propensity for inter-regional co-operation than private sector firms. Thus, hypothesis 4 is confirmed with respect to our sample. It is remarkable that the majority of the universities show also relatively high involvement in 
regional co-operation activities so that their inter-regional orientation is not at the expense of intra-regional links. In the field of basic research, the universities exhibit even the highest propensity for intra-regional co-operation as compared to all other organization types. The majority of non-university PROs' actors are not involved in regional R\&D cooperation with regard to product and process innovation with partners external to the innovation network under study. Except for process innovation their propensity for inter-regional cooperation turns out to be relatively low compared to the universities (table 2). Manufacturing firms and service firms in our sample clearly tend to ally with $R \& D$ cooperation partners located in the same region (table 2). Just 40 percent of the firms stated that they conduct R\&D cooperation with partners external to their region. Although more than 60 percent of the firms undertake basic research in co-operation with regional partners, their propensity for inter-regional cooperation in basic research is relatively low ( 22 percent). These findings confirm our supposition in section 2.3.

Our results show that public research organizations that are engaged in inter-regional R\&D cooperation tend to transfer more knowledge to network partners than those that do not cooperate with R\&D partners external to their region (figure 4). Correlation analyses reveal that universities' extent of knowledge transfer is positively related to the frequency of $R \& D$ cooperation they undertake in the fields of product innovation and process innovation with partners external to their region. ${ }^{21}$ Universities' frequency of inter-regional cooperation in basic research, however, has no influence on the extent of knowledge transfer to network partners. Similarly, the non-university PROs' extents of knowledge transfer increase significantly if they maintain inter-regional co-operation in product innovation. ${ }^{22}$ But even if one considers this gatekeeper effect of non-university PROs, the amount of knowledge transferred by university actors (gatekeeping as well as non-gatekeeping) is on average much larger. This supports our hypothesis 5 stating that public research organiza- 
tions fulfill a gatekeeper function for SMEs located in the same region. This pertains especially to university actors which (often) conduct inter-regional cooperation in product and process innovation.

- insert "Figure 4: Inter-regional cooperation activity and knowledge transfer to network partners" about here -

With respect to the firms, we found no statistical relationship between the mere existence of inter-regional $\mathrm{R} \& \mathrm{D}$ cooperation activity and the extent of knowledge transfer to network partners (figure 4). But analogous to universities, the firms' frequency of interregional cooperation is positively correlated with the extent of their knowledge transfer. ${ }^{23}$ Considering, however, the small proportion of firms that undertake such inter-regional R\&D-cooperation (table 2) one may conclude that the group of private firms in our sample cannot be seen as central gatekeepers of knowledge.

With regard to knowledge acquisition we find that firms without access to interregional knowledge sources rely relatively strongly on the partners of their regional innovation network (figure 5): Manufacturing firms without inter-regional cooperation activity in basic research and service firms with no inter-regional cooperation activity in basic research or product innovation acquire significantly more knowledge from their network partners than firms that undertake such inter-regional cooperation activity. Probably, firms without such inter-regional cooperation activity especially rely on (public research) partners that provide access to inter-regional knowledge sources. In other words: Relying on (gatekeeping) network partners to attain new knowledge that is diverse to the regional knowledge base obviously is less important if a firm is on its own linked with cooperation partners external to its region. These results, in addition to the former findings of section 
- insert "Figure 5: Firms' inter-regional cooperation activity and the extent of knowledge acquired from network partners" about here-

4.4, indicate that the gatekeeper function (of public research) is existent within regional networks of innovation.

For public research organizations the gatekeeper and broker function seem to be related: RROs that cooperate in $\mathrm{R} \& \mathrm{D}$ with partners external to their region hold on average 18 broker positions, whereas public research actors without inter-regional R\&D cooperation activity assume only about 4 broker positions. One reason for this difference is a lower number of direct partners in the respective ego-networks (all network partners one is directly connected to): The gatekeeping PROs have larger numbers of direct partners as compared to non-gatekeeping PROs. A second reason is a significantly lower density of the gatekeeping universities' ego networks compared to the non-gatekeeping universities. This implies that non-gatekeeping universities tend to be involved in dense regional subnetworks (clans) where most of the partners are linked to each other. Such a type of network provides only marginal opportunities for brokerage and involves the danger of lockin processes. However, two third of the universities' actors involved in the networks under study belong to the group of gatekeepers. Thus, the phenomenon does not conflict with the general conclusion of our study that the universities are essential players in regional systems of innovation.

\section{SUMMARY AND CONCLUSIONS}

Our analysis of the different types of organizations in regional innovation systems clearly shows that public research organizations can be regarded as central actors in regional inno- 
vation networks. Firstly, they have more direct partners than private firms (degree, size of ego networks). Secondly, as several centrality measures show (betweenness centrality, number of broker positions), they more often link network members that are not directly connected to one another than the private firms in our sample do. With regard to knowledge exchange within the networks, however, we found substantial differences within the public research sector: Universities not only transfer a higher extent of knowledge to their network partners than private sector firms do, they also transfer a significantly higher extent of knowledge than non-university PROs. Moreover, the extent of knowledge absorbed by universities turns out to be significantly higher than that absorbed by non-university PROs. Thus, universities outperform non-university research organizations, which tend to engage poorly in the knowledge exchange processes of their regional innovation networks. This result is quite surprising given that almost all of the non-university PROs in the networks under study mainly conduct applied research. We cannot completely rule out that our results regarding the different types of research organizations may be shaped by differences in their local conditions: While most universities are located in central cities, at least some of the non-university research organizations in our sample have locations in more remote places that are characterized by a small stock of innovative firms, which might partly explain their relatively poor transfer performance.

Based on the assumption that knowledge flows within a network do not exclusively result from direct ties but also are fostered by indirect links, we investigated the relation between broker positions and knowledge exchange. In this context, we found striking differences between the organization types: For the universities and for the manufacturing firms, the mere existence of a broker position as well as the number of broker positions held were positively related to their extent of knowledge transfer to network partners. Apparently, their broker positions tend to transform into a broker function with social benefits 
for other organizations in the network. Moreover, universities as well as manufacturing firms attain private benefits due to their broker positions because they acquire knowledge from their network partners to a significantly higher extent than those without broker positions. However, with regard to non-university PROs in broker positions, we neither found a higher degree of their knowledge absorption nor of their knowledge transfer. Thus, nonuniversity PROs do not generate substantial social benefits with regard to knowledge transfer and they also do not gain private benefits from the broker positions they assume. There could be several explanations for this result: Either the non-university PROs are not very interested in brokerage or the knowledge domains of their partners are more heterogeneous than those of the universities' partners which may cause reduced opportunities for brokering. But, as argued above, it is also possible that insufficient capabilities of their network partners prevent their broker positions from transforming into broker functions. That the service firms make no use of their broker position may result from their partner structure: They often cooperate with different manufacturing firms that might be competitors and so are wary of unintended knowledge spillovers. In general we found that the "typical broker firm" can be characterized by a relatively large firm size and high R\&D-capacities.

Furthermore, our results show that public research organizations are much better linked to global knowledge sources by their inter-regional R\&D partnerships than the private firms in our sample. The majority of universities are also linked to regional partners, which is one of the preconditions to fill a gatekeeper function that involves the absorption of globally dispersed knowledge and its transfer to regional innovation partners, especially to firms. Indeed, we found that the universities' frequency of inter-regional co-operation activity in product and process innovations is positively related to the extent that knowledge is transferred to partners within the regional innovation network. This implies that there needs to be a certain overlap with respect to the knowledge domains of the transferor 
and the transferee that would not arise if universities undertook only inter-regional cooperation in basic research. With regard to non-university PROs as well as the private firms we got similar results concerning the gatekeeper function. However, gatekeeping nonuniversity research organizations on average cannot attain the knowledge transfer level of the non-gatekeeping universities. Furthermore, non-university research organizations are considerably less involved in regional $\mathrm{R} \& \mathrm{D}$ cooperation activities than universities. Thus, they are not the central gatekeepers of knowledge in their regional innovation system. Although some private sector firms may act as important gatekeepers and players in a regional innovation system most of them do not as is reflected in the small proportion of firms that undertake inter-regional R\&D cooperation.

In summary, we found compelling evidence that most of the universities in our sample make an enormous contribution to knowledge exchange activities within their regional network of innovation. There can be little doubt that universities are the central brokers and gatekeepers of knowledge, because they are well connected to global pipelines and integrated into local buzz. Our results indicate that universities' gatekeeper function can help those firms, in particular, which do not have inter-regional R\&D partnerships to increase their knowledge stocks. Thus, regionalized innovation policy should specifically attempt to integrate those scientists into networking activities who already show frequent inter-regional R\&D cooperation in product and process innovation. Additionally, the weak local linkages of non-university PROs, which basically exhibit transfer potential, should be extended and strengthened. Thirdly, policy measures should be directed to the enhancement of PROs inter-regional cooperation activity in product and process innovation.

Since our analysis was conducted for networks in less favored regions of a developed country we cannot preclude that the results mainly hold for this spatial category. Perhaps, 
the share of firms with access to inter-regional knowledge sources by their own R\&Dactivities is higher in more developed regions. Under such conditions firms may be less dependent on knowledge transfer from public research organizations and may also be better prepared to operate as gatekeepers of knowledge for other firms. It should also be mentioned that although the integration of PROs in regional innovation networks can be very supportive for local SMEs without direct international links, they can hardly provide effective support regarding international commercialization. 
APPENDIX

Table A1: Definition of variables

\begin{tabular}{|c|c|c|}
\hline Variable & Description & Indicator \\
\hline $\begin{array}{l}\text { Information } \\
\text { transfer }\end{array}$ & $\begin{array}{l}\text { Information a } \\
\text { network member } \\
\text { has transferred to } \\
\text { his partners }\end{array}$ & $\begin{array}{l}\text { Did your network partner benefit } \\
\text { from your information or } \\
\text { suggestions? }\end{array}$ \\
\hline $\begin{array}{l}\text { Information } \\
\text { absorption }\end{array}$ & $\begin{array}{l}\text { Information a } \\
\text { network member } \\
\text { has received from } \\
\text { his partners }\end{array}$ & $\begin{array}{l}\text { Did you receive information, } \\
\text { suggestions or other stimulation fror } \\
\text { your network partner(s)? }\end{array}$ \\
\hline $\begin{array}{l}\text { Knowledge } \\
\text { transfer }\end{array}$ & $\begin{array}{l}\text { Knowledge a } \\
\text { network member } \\
\text { has transferred to } \\
\text { his partners }\end{array}$ & $\begin{array}{l}\text { Did your network partner(s) benefit } \\
\text { from your technical/professional } \\
\text { assistance? }\end{array}$ \\
\hline $\begin{array}{l}\text { Knowledge } \\
\text { absorption }\end{array}$ & $\begin{array}{l}\text { Knowledge a } \\
\text { network member } \\
\text { has received from } \\
\text { his partners }\end{array}$ & $\begin{array}{l}\text { Did you receive technical/ } \\
\text { professional assistance from your } \\
\text { network partner(s)? }\end{array}$ \\
\hline $\begin{array}{l}\text { Degree/Ego- } \\
\text { network }\end{array}$ & $\begin{array}{l}\text { Degree/ego- } \\
\text { network of an } \\
\text { organization }\end{array}$ & $\begin{array}{l}\text { Direct links/an organizations' (i) } \\
\text { ego-network covers all network } \\
\text { partners (organizations) that are } \\
\text { linked directly to (i) }\end{array}$ \\
\hline Betweenness & $\begin{array}{l}\text { Betweenness of an } \\
\text { organization }\end{array}$ & $\begin{array}{l}\text { An organization is located on the } \\
\text { "shortest path" of two other } \\
\text { organizations that are not linked } \\
\text { directly }\end{array}$ \\
\hline
\end{tabular}

Broker yes/no

(n) number of broker positions

\section{Existence of a broker position}

Number of broker positions

Number of broker positions an
Inter-regional

$R \& D$

cooperation activity

Inter-regional

$\mathrm{R} \& \mathrm{D}$

cooperation intensity
Existence of interregional $R \& D$ activities

Inter-regional $\mathrm{R} \& \mathrm{D}$ cooperation frequency organization is located in

If an organization is located in at least one broker position

Do you undertake R\&D with partners external to the region (in basic research, product or process development)?

How often do you undertake R\&D with partners external to the region (in basic research, product development, process development)?

\section{5-point Likert-Scale}

(very few - very much)

5-point Likert-Scale

(very few - very much)

Number of direct links (partners)

Frequency an organization (i) is located on the geodesic distance of two other organizations ( $\mathrm{jk})$ that are not linked directly; distance-based measure

An organization (i) links to other organizations (jk) that are not linked directly

The frequency an organization (i) links to other organizations (jk), that are not linked directly (standardized for the size of the respective ego-network)

Yes/no; aggregated to the organizational level (means)

5-point Likert-Scale (not at all very much); aggregated to the organizational level (means) 
Table A2: Descriptive statistics

\begin{tabular}{|c|c|c|c|c|c|c|}
\hline & $\begin{array}{l}\text { Number of } \\
\text { observations }\end{array}$ & Mean & Minimum & Maximum & $\begin{array}{l}\text { Standard } \\
\text { deviation }\end{array}$ & $\begin{array}{l}\text { Coefficient } \\
\text { of Variation }\end{array}$ \\
\hline $\begin{array}{l}\text { Information } \\
\text { absorbed }\end{array}$ & 334 & 3.54 & 1 & 5 & 1.01 & 1.01 \\
\hline $\begin{array}{l}\text { Knowledge } \\
\text { absorbed }\end{array}$ & 334 & 3.51 & 1 & 5 & 1.07 & 1.15 \\
\hline $\begin{array}{l}\text { Information } \\
\text { transferred }\end{array}$ & 336 & 3.46 & 1 & 5 & 0.85 & 0.73 \\
\hline $\begin{array}{l}\text { Knowledge } \\
\text { transferred }\end{array}$ & 336 & 3.34 & 1 & 5 & 0.91 & 0.84 \\
\hline $\begin{array}{l}\text { Degree/Ego- } \\
\text { network size }\end{array}$ & 338 & 3.41 & 0 & 29 & 2.98 & 8.88 \\
\hline $\begin{array}{l}\text { Degree } \\
\text { (normalized) }\end{array}$ & 338 & 17.57 & 0 & 100 & 15.69 & 246.29 \\
\hline $\begin{array}{l}\text { Betweenness } \\
\text { (normalized) }\end{array}$ & 338 & 5.41 & 0 & 76.38 & 12.21 & 149.00 \\
\hline Broker yes/no & 338 & 0.68 & 0 & 1 & 0.467 & 0.22 \\
\hline $\begin{array}{l}\text { Number of } \\
\text { broker positions }\end{array}$ & 338 & 6.75 & 0 & 367 & 29.69 & 881.50 \\
\hline $\begin{array}{l}\text { (n) Number of } \\
\text { broker positions } \\
\text { (normalized) }\end{array}$ & 337 & 0.22 & 0 & 0.50 & 0.179 & 0.03 \\
\hline $\begin{array}{l}\text { Inter-regional } \\
\text { R\&D } \\
\text { cooperation } \\
\text { activity }\end{array}$ & 339 & 0.56 & 0 & 1 & 0.496 & 0.25 \\
\hline $\begin{array}{l}\text { Inter-regional } \\
\mathrm{R} \& \mathrm{D}- \\
\text { cooperation } \\
\text { frequency }\end{array}$ & 334 & 3.31 & 1 & 5 & 0.94 & 0.88 \\
\hline
\end{tabular}




\section{NOTES}

1. At the firm level, TUSHMAN and KATZ (1980) found that gatekeepers positively affect the performance of $R \& D$ projects within $R \& D$ units.

2. All of these regions are of about the same geographical size.

3. For example, bio-technology, medical technology, automotive, innovative textiles, phytopharma, health industry, musical instruments.

4. Five of the networks that were involved in the InnoRegio initiative have been excluded from the study either because of very small numbers of participating actors or because of their particular innovation objectives (e.g. "social" innovations such as barrier-free tourism).

5. Number of organizations: 142 manufacturing firms, 80 service firms, 35 universities, 27 non-university public research organizations, 28 private research organizations, and 26 other organizations (e.g. educational institutions, regional agencies of business development). The majority of the public research organizations belong to the Fraunhofer Association. Max-Planck Institutes are hardly involved in the networks.

6. More than $500 \mathrm{R} \& \mathrm{D}$-projects were conducted and granted in the program. They differ considerably in regard to their research topics, duration, financial volume, and partners involved. However, the subsidies were basically restricted to the early stage of innovation.

7. The networks were restricted to organizations that have been funded by the policy program.

8. We assume that an organization has transferred information and knowledge to a certain network member if it was named by this network member as an important partner. Absorption takes place if an organization named a certain network member as an important partner. Thus, mutual information and knowledge exchange only occurs if two organizations name each other as important partners.

9. See section 4.2.2 for measurement details. 
10. Probably for this reason, AHUJA (2000) found that indirect connections among firms positiverly addect innovation, although the effect is moderated by direct ties.

11. Private firms' share of knowledge they transferred amounts to 48 percent (PROs $=43$ percent). Thus, the numerical dominance of private firms does not crowd out PROs' meaningful transfer value.

12. Knowledge transfer as well as knowledge absorption of non-university PROs turns out to be significantly lower than the universities' (at the 5-percent level; Mann-Whitney-Test).

13. The standardized measure corresponds to the degree of an organization divided by the maximal possible degree that is calculated on the basis of the total number of organizations, multiplied by 100 . Thus, the standardized measure takes the network size effects into consideration.

14. Statistically significant at the 1-percent level (Mann Whitney-Test).

15. The correlation coefficient is 0.125 (statistically significant at the 5-percent level). With respect to the universities, we found a positive, but insignificant, correlation coefficient of 0.144. The correlation coefficient for the non-university PROs had a non-significant negative value.

16. The public research organization that is located at the middle of the top in figure 3 may serve as an example. For calculating the broker measure, the organizations' direct relations (ego network) are taken into account which amount to 5. Thus, for this actor a maximum of 20 broker positions $(\mathrm{n} *(\mathrm{n}-1))$ is attainable. According to figure 3, this public research organization is linked to 5 pairs of organizations that are not connected directly. Additionally, the organization connects 4 other pairs of organizations that are not linked reciprocally but only in one direction. Such links in which knowledge is only transferred in one direction are only counted as 0.5 . As a result, the calculation of the number of broker positions accounts for the exchange directions. Altogether, the examined public research organization attains 7 broker positions $(5+(4 *(0,5))$.

17. All mentioned differences between brokers and non-brokers are statistically significant at the 5-percent level of significance. 
18. In three out of the 18 networks, one university has an enormous number of broker positions (367, 94 and 92.5 broker positions, respectively).

19. Whitney-Mann tests are applied to test for differences between the two groups "with / without broker positions" concerning knowledge transfer and knowledge absorption. Correlation analysis (kendall-tau-b) is employed to show the relationship between the number of broker positions and knowledge exchange (transfer and absorption).

20. Those seven universities that do not assume a broker position in the networks under study also show an extremely low level of knowledge exchange with network partners. In cases where a university does not have at least one broker position in a network, the innovation activity of the network does not predominantly rely on academic knowledge. We know from our inquiry that these universities do also exchange knowledge with other actors, but these actors do not participate in the respective network.

21. The correlation coefficient (Pearson) for product innovation is 0.474 (statistically significant at the 1-percent level) and for process innovation it is 0.337 (statistically significant at the 5-percent level).

22. Significant differences at the 10-percent level between the two groups "with/without interregional cooperation activity in product innovation".

23. The correlation coefficient (Pearson) is 0,243 (statistically significant at the 5-percent level). 


\section{REFERENCES}

AHUJA, G. (2000) Collaboration networks, Structural Holes, and Innovation: A Longitudinal Study, Administrative Science Quarterly 45, 425-455.

AGRAWAL A. and COCKBURN I. (2003) The Anchor Tenant Hypothesis: Exploring the Role of Large, Local, R\&D-intensive Firms in Regional Innovation Systems, International Journal of Industrial Organization 21, 1227-53.

ALBINO V., GARAVELLI A. C. and SCHIUMA G. (1999) Knowledge Transfer and Inter-firm Relationship: The Role of the Leader Firm, Technovation 19, 53-63.

ALLEN T. J. (1977) Managing the Flows of Technology: Technology Transfer and the Dissemination of Technological Information within the R\&D Organization. MIT Press.

ASHEIM B. T. and ISAKEN A. (2002) Regional Innovation Systems: The Integration of Local "Sticky" and Global Ubiquitous Knowledge, Journal of Technology Transfer 27, 77-86.

AUDRETSCH D. B. and FELDMAN M. P. (1996) R\&D Spillovers and the Geography of Innovation and Production, American Economic Review 86, 630-40.

BATHELT H., MALMBERG A. and MASKELL P. (2004) Clusters and Knowledge: Local Buzz, Global Pipelines and the Process of Knowledge Creation, Progress in Human Geography 28, 3156.

BIGGIERO L. (2002) The Location of Multinationals in Industrial Districts: Knowledge Transfer in Biomedicals, Journal of Technology Transfer 27, 111-22.

BMBF (2005) Das BMBF-Förderprogramm InnoRegio - Ergebnisse der Begleitforschung, Unternehmen Region: Die BMBF-Innovationsoffensive Neue Länder. Bundesministerium für Bildung und Forschung, Bonn, Berlin.

BOARI C. and LIPPARINI A. (1999) Networks within Industrial Districts: Organizing Knowledge Creation and Transfer by Means of Moderate Hierarchies, Journal of Management and Governance 3, 339-60.

BOSCHMA R. (2005) Proximity and innovation: A critical assessment, Regional Studies 39, 61-74. 
BOSCHMA R. A. and LAMBOOY J. G. (1999) Evolutionary Economics and Economic Geography, Journal of Evolutionary Economics 9, 411-429.

BRESCHI S. and LISSONI F. (2001) Knowledge Spillovers and Local Innovation Systems: A Critical Survey, Industrial and Corporate Change 10, 975-1005.

BURT R. S. (2005) Brokerage and Closure: An Introduction to Social Capital, Oxford University Press.

CAMAGNI R. (Ed) (1991) Innovation Networks: Spatial Perspectives. Belhaven-Printer, London.

CAMAGNI R. (1995) Global Network and Local Milieux: Towards a Theory of Economic Space, in CONTI S., MALECKI E. J. and OINAS P. (Eds) The Industrial Enterprise and its Environment: Spatial Perspectives, pp. 195-216. Avebury, Aldershot.

CANTNER U. and GRAF H. (2006) The Network of Innovators in Jena: An Application of Social Network Analysis, Research Policy 35, 463-80.

CAPELLO R. (1999) Spatial Transfer of Knowledge in High Technology Milieux: Learning Versus Collective Learning Processes, Regional Studies 33, 353-65.

CARLSSON B. (1994) Technological Systems and Economic Performance, in Dogson, M. and Rothwell, R. (Eds) The Handbook of Industrial Innovation, 13-24. Edward Elgar, Cheltenham.

COHEN W. M. and LEVINTHAL D. A. (1990) Absorptive Capacity: A new perspective on learning and innovation, Administrative Science Quarterly 35, 128-52.

COWAN R., DAVID P. A. and FORAY D. (2000) The Explicit Economics of Knowledge Codification and Tacitness, Industrial and Corporate Change 9, 211-53.

COOKE P., HEIDENREICH M. and BRACZYK H.-J. (Eds) (2004) Regional Innovations Systems. The Role of Governances in a Globalized World. 2nd Edition. Routledge, New York.

CRANEFIELD J. and YOONG P. (2007) Inter-organizational knowledge transfer: the role of the gatekeeper, International Journal of Knowledge and Learning 3, 121-38.

CROWLEY C. (2007) An Application of Social Network Analysis to Marshall's Industrial District Model, DRUID Winter Conference 2007. 
CROSS R., BORGATTI S. and PARKER A. (2002) Making Invisible Work Visible: Using Social Network Analysis to Support Strategic Collaboration, California Management Review 44, 24-46.

DAHL M. S. and PEDERSEN C. O. R. (2004) Knowledge Flows through Informal Contacts in Industrial Clusters: Myth or Reality? , Research Policy 33, 1673-86.

DAS T. K. and TENG B. S. (2001) Trust, Control and Risk in Strategic Alliances: An Integrated Framework, Organization Studies 22, 251-83.

DASGUPTA P. and DAVID P. (1987) Information disclosure and the Economics of Science and Technology, in FEIWEL G. R. (Ed) Arrow and the Ascent of Modern Economic Theory, pp. 51942. New York University Press, New York.

DASGUPTA P. and DAVID P. A. (1994) Towards a New Economics of Science, Research Policy $23,487-521$.

DOSI G. (1982) Technological Paradigms and Technological Trajectories: A suggested Interpretation of the Determinants and Directions of Technical Change, Research Policy 11, 147-62.

EICKELPASCH A. and FRITSCH M. (2005) Contests for Cooperation: A new Approach in German Innovation Policy, Research Policy 34, 1269-82.

EICKELPASCH A., KAUFFELD M., PFEIFFER I., WURZEL U. and BACHMANN T. (2002a) The InnoRegio Initiative - the Concept and First Results of the Complementary Research, DIW Berlin Series: Economic Bulletin 39, 33-43.

EICKELPASCH A., KAUFFELD M. and PFEIFFER I. (2002b) The InnoRegio Programme: Implementing the Promotion and Developing the Networks, DIW Berlin Series: Economic Bulletin 39, 281-90.

FELDMAN M. P. (1994) The Geography of Innovation. Kluwer, Dordrecht.

FONTES M. (2005) Distant networking: The knowledge acquisition strategies of 'out-cluster' biotechnology firms, European Planning Studies 13, 899-920.

FRANZONI C. and LISSONI F. (2008) Academic Entrepreneurship, Patents, and Spin-Offs: Critical Issues and Lessons for Europe, in VARGA A. (Ed) Universities and Regional Economic Development. Edward Elgar, Cheltenham. 
FRITSCH M. (2004) Cooperation and the Efficiency of Regional R\&D Activities, Cambridge Journal of Economics 28, 829-46.

FRITSCH M. and SCHWIRTEN C. (1999) Enterprise-University Co-operation and the Role of Public Research Institutions in Regional Innovation Systems, Industry and Innovation 6, 69-83.

FRITSCH M. and SLAVTCHEV V. (2007) Universities and Innovation in Space, Industry and Innovation 14, 201-18.

FRITSCH M. and KAUFFELD-MONZ M. (2010) The Impact of Network Structure on Knowledge Transfer: An Application of Social Network Analysis in the Context of Regional Innovation Networks, Annals of Regional Science, 44, 21-38.

GEENHUIZEN M. V. (2007) Modelling dynamics of knowledge networks and local connectedness: a case study of urban high-tech companies in The Netherlands, Annals of Regional Science 41, 81333.

GERTLER M. and LEVITTE Y. (2005) Local Nodes in Global Networks: The Geography of Knowledge Flows in Biotechnology Innovation, Industry and Innovation 12, 487-507.

GIULIANI E. (2005) Cluster Absorptive Capacity: Why do some clusters forge ahead and others lagging behind?, European Urban and Regional Studies 12, 269-88.

GIULIANI E. and BELL M. (2005) The micro-determinants of meso-level learning and innovation: evidence from a Chilean wine cluster, Research Policy 34, 47-68.

GLASMEIER A. (1994) Flexible Districts, flexible Regions? The Institutional and Cultural Limits to Districts in the Era of Globalization and Technological Paradigm Shifts, in AMIN A. and THRIFT N. (Eds) Globalization, institutions, and regional development in Europe, pp. 118-46. Oxford University Press, Oxford.

GRABHER G. (1993) The weakness of strong ties: the lock-in of regional development in the Ruhr area, in GRABHER G. (Ed) The Embedded Firm - On the Socioeconomics of Industrial Networks, pp. 255-77. Routledge, London, New York.

GRABHER G. (2002) The project ecology of advertising: tasks, talents and teams, Regional Studies $36,245-62$. 
GRAF H. (2007) Gatekeepers in Regional Networks of Innovators, Jena Economic Research Papers 2007-054.

GRAF H. and HENNING T. (2009) Public Research in Regional Networks of Innovators: A Comparative Study of Four East-German Regions, Regional Studies 43, 1349-1368.

HALL B. H., LINK A. N. and SCOTT J. T. (2001) Barriers Inhibiting Industry from Partnering with Universities: Evidence from Advanced Technology Program, Journal of Technology Transfer 26, $87-98$.

HARADA T. (2003) Three steps in knowledge communication: the emergence of knowledge transformers, Research Policy 32, 1737-51.

HARGADON A. and SUTTON R. I. (1997) Technology Brokering and Innovation in a Product Development Firm, Administrative Science Quarterly 42, 716-49.

HARPER J. S. and RAINER R. K. (2000) Analysis and Classification of Problem Statements in Technology Transfer, Journal of Technology Transfer 25, 135-56.

HOWELLS J. (2006) Intermediation and the Role of Intermediarities in Innovation, Research Policy $35,715-28$.

JAFFE A. B., TRAJTENBERG M. and HENDERSON R. (1993) Geographic localization of knowledge spillovers as evidenced by patent citations, Quarterly Journal of Economics 63, 576-98.

JANSEN D. (1999) Einführung in die Netzwerkanalyse. Leske + Budrich, Opladen.

KIM S.-R. and TUNZELMANN N. V. (1998) Aligning internal and external networks: Taiwan's specialization in IT, SPRU (Science Policy Research Unit, University of Sussex) - Electronic Working Paper Series No. 17.

KNORRINGA P. (1996) Economics of collaboration: Indian Shoemakers between Market and Hierarchy. Sage Publications, Thousand Oaks, CA.

KRONTHALER F. (2005) Economic Capability of East German Regions: Results of a Cluster Analysis, Journal of Technology Transfer 39, 739 - 50.

LAWSON C. and LORENZ E. (1999) Collective Learning, Tacit Knowledge and Regional Innovative Capacity, Regional Studies 33, 305-17. 
LAZERSON M. H. and LORENZONI G. (1999) The Firms that feed Industrial Districts: A Return to the Italian Source, Industrial and Corporate Change 8, 235-66.

LINDHOLM-DAHLSTRAND A. (1999) Technology-based SMEs in the Göteborg Region: Their Origin and Interaction with Universities and Large Firms, Regional Studies 33, 379-89.

LONGHI C. (1999) Networks, Collective Learning and Technology Development in Innovative High Technology Regions: The Case of Sophia-Antipolis, Regional Studies 33, 333-42.

MARSHALL A. (1927) Industry and Trade. A Study of Industrial Technique and Business Organization and Their Influences on the Conditions of Various Classes and Nations. 3rd edition. Macmillan, London.

MALMBERG A. and MASKELL P. (2002) The elusive concept of localization economies: towards a knowledge-based theory of spatial clustering, Environment and Planning 34, 429-49.

MERTON R. (1936) The unintended consequences of purposive social action, American Sociological Review 1, 894-904.

MORRISON A. (2008) "Gatekeepers of Knowledge" within Industrial Districts: Who They Are, How They Interact, Regional Studies 42, 817-35.

MUNARI F., MALIPIERO A. and SOBRERO M. (2005) Focal firms as technological gatekeepers within industrial districts: Evidence from the Packaging Machinery Industry, DRUID Working Paper No. 05-05.

NELSON R. R. and WINTER S. (1982) An Evolutionary Theory of Economic Change. Harvard University Press, Cambridge MA.

NONAKA I. (1991) The Knowledge Creating Company, Harvard Business Review 69.

NOOTEBOOM B. (2003) Problems and Solutions in Knowledge Transfer, in FORNAHL D. and BRENNER T. (Eds) Cooperation, Networks and Institutions in Regional Innovation Systems, pp. 105-127. Edward Elgar, Northampton.

OERLEMANS L., MEEUS M. and BOEKEMA F. (2001) Firm Clustering and Innovation: Determinants and Effects, Papers in Regional Science 80, 337-56.

OWEN-SMITH J. and POWELL W. W. (2004) Knowledge Networks as Channels and Conduits: Spillover in the Boston Biotechnology Community, Organization Science 15, 5-21. 
POUDER R. and ST. JOHN C. H. (1996) Hot spots and blind spots: Geographical clusters of firms and innovation, Academy of Management Journal 21, 1192-225.

SABEL C. F. (1989) Flexible Specialization and the Reemergence of Regional Economies, in HIRST P. and ZEITLIN J. (Eds) Reversing Industrial Decline. St. Martin's Press, New York.

SAPSED J., GRANTHAM A. and DEFILLIPPI R. (2007) A bridge over troubled waters: Bridging organizations and entrepreneurial opportunities in emerging sectors, Research Policy 36, 1314-34.

SCHMOCH U. (1999) Interaction of Universities and Industrial Enterprises in Germany and the United States - A Comparison, Industry and Innovation 6, 51-68.

SCOTT A. (1996) Regional Motors of the Global Economy, Futures 28, 391-411.

SHAPIRO S. P. (1987) The Social Control of Impersonal Trust, American Journal of Sociology 93, $623-58$.

STORPER M. and VENABLES A. J. (2004) Buzz: Face-to-face contact and the urban economy, Journal of Economic Geography 4, 351-70.

SWANN P. (1998) Towards a model of clustering in high-technology industries, in SWANN P., PREVEZER M. and STOUT D. (Eds) The dynamics of industrial clustering, pp. 52-76. Oxford University Press, Oxford.

TUSHMAN M.L. and KATZ R. (1980) External Communication and Projekt Perfromance: An Investigation into the Role of Gatekeepers, Management Science 26, 1071-1086.

VAN LOOY B., DEBACKERE K. and ANDRIES P. (2003) Policies to stimulate regional innovation capabilities via university-industry collaborations: an analysis and an assessment, $R \& D$ Management 33, 209-29.

VARGA A. (2000) Universities in Local Innovation Systems, in ZOLTAN J. and ACS J. (Eds) Regional Innovation, Knowledge and Global Change, pp. 139-52. Pinter, London.

VEUGELERS R. and CASSIMAN B. (1999) Importance of International Linkages for Local Knowhow Flows. Some econometric Evidence from Belgium, CEPR (Center for Economic Policy Research) Discussion Paper Series No. 2337. 
WATERS R. and LAWTON-SMITH H. (2002) Regional Development Agencies and Local Economic Development: Scale and Competitiveness in High-technology Oxfordshire and Cambridgeshire, European Planning Studies 10, 633-49.

WINK R. (2008) Gatekeepers and Proximity in Science-driven Sectors in Europe and Asia: The Case of Human Embryonic Stem Cell Research, Regional Studies 42, 777-91.

ZUCKER L. G. (1986) Production of Trust: Institutional Sources of Economic Structure, Research in Organizational Behavior 8, 53-111. 
Table 1: Broker positions and their relation to knowledge exchange*

\begin{tabular}{|c|c|c|c|c|c|}
\hline & & \multirow{2}{*}{$\begin{array}{l}\text { Share of organizations } \\
\text { with / without } \\
\text { at least one broker } \\
\text { position } \\
\text { (in \%) }\end{array}$} & \multirow{2}{*}{$\begin{array}{l}\text { Number of } \\
\text { broker positions } \\
\text { (on average) }\end{array}$} & \multicolumn{2}{|c|}{$\begin{array}{c}\text { Statistical relation to } \\
\text { knowledge ... }\end{array}$} \\
\hline & & & & transfer & absorption \\
\hline Type of organization & & (1) & (2) & (3) & (4) \\
\hline \multirow{2}{*}{$\begin{array}{l}\text { Manufacturing firms }(\mathrm{N}= \\
137)\end{array}$} & $(1)$ & $56 / 44$ & & $3.37 / 2.95 * *$ & $3.95 / 3.48 * *$ \\
\hline & (2) & & 2,6 & $.145 * *$ & .110 \\
\hline \multirow{2}{*}{ Service firms $(\mathrm{N}=77)$} & (3) & $81 / 19$ & & $3.51 / 3.73$ & $3.26 / 3.40$ \\
\hline & $(4)$ & & 4 & -.124 & -.058 \\
\hline \multirow{2}{*}{ Universities $(\mathrm{N}=35)$} & $(5)$ & $80 / 20$ & & $3.65 / 2.79 * *$ & $3.77 / 2.57 * *$ \\
\hline & $(6)$ & & 22,15 & $.295 * *$ & .174 \\
\hline \multirow{2}{*}{$\begin{array}{l}\text { Non-university public } \\
\text { research organizations } \\
(\mathrm{N}=27)\end{array}$} & $(7)$ & $67 / 33$ & & $3.37 / 3.33$ & $3.46 / 2.78$ \\
\hline & (8) & & 5,65 & -.143 & .026 \\
\hline \multicolumn{6}{|c|}{ ** significant at 5-percent level } \\
\hline
\end{tabular}


Table 2: Regional and inter-regional cooperation activity by organization types (in \%)

\begin{tabular}{|c|c|c|c|c|c|c|c|}
\hline \multirow[b]{3}{*}{$\begin{array}{l}\text { Actors from ... } \\
\text { (by type of organization) }\end{array}$} & \multicolumn{7}{|c|}{$\begin{array}{l}\text { Regional / inter-regional cooperation exists in the field of ... } \\
\qquad \text { (in } \% \text { of organizations) }{ }^{*}\end{array}$} \\
\hline & \multicolumn{2}{|c|}{ Basic research } & \multicolumn{2}{|c|}{ Product innovation } & \multicolumn{2}{|c|}{ Process innovation } & \multirow{2}{*}{$\begin{array}{l}\text { Any inter- } \\
\text { regional } \\
\text { coopera- } \\
\text { tion exist }\end{array}$} \\
\hline & regional & $\begin{array}{l}\text { inter- } \\
\text { regional }\end{array}$ & regional & $\begin{array}{l}\text { inter- } \\
\text { regional }\end{array}$ & regional & $\begin{array}{l}\text { inter- } \\
\text { regional }\end{array}$ & \\
\hline Manufacturing firms & 61.0 & 22.9 & 65.4 & 35.1 & 60.5 & 31.2 & 45.3 \\
\hline Service firms & 68.5 & 22.3 & 66.9 & 29.2 & 64.6 & 28.5 & 38.0 \\
\hline Universities & 71.7 & 60.4 & 58.5 & 44.3 & 52.8 & 36.8 & 67.6 \\
\hline $\begin{array}{l}\text { Non-university public } \\
\text { research organizations }\end{array}$ & 60.8 & 54.9 & 41.2 & 37.3 & 41.2 & 39.2 & 64.7 \\
\hline $\begin{array}{l}\text { Private research organiza- } \\
\text { tions }\end{array}$ & 62.3 & 63.9 & 68.9 & 57.4 & 63.8 & 52.5 & 78.3 \\
\hline
\end{tabular}


Nodes $=$ organizations; lines $=$ exchange relations; size of symbols $=$ extent of knowledge transfer to network partners (means per organization; measured at a scale from 1 to 5 ).

Circle/circle in box $=$ manufacturing firms/service firms; up triangle $=$ universities; down triangle $=$ nonuniversity public research organization; diamonds = institutions of basic and advanced training and other.

Figure1: Knowledge transfer within one of the networks studied 


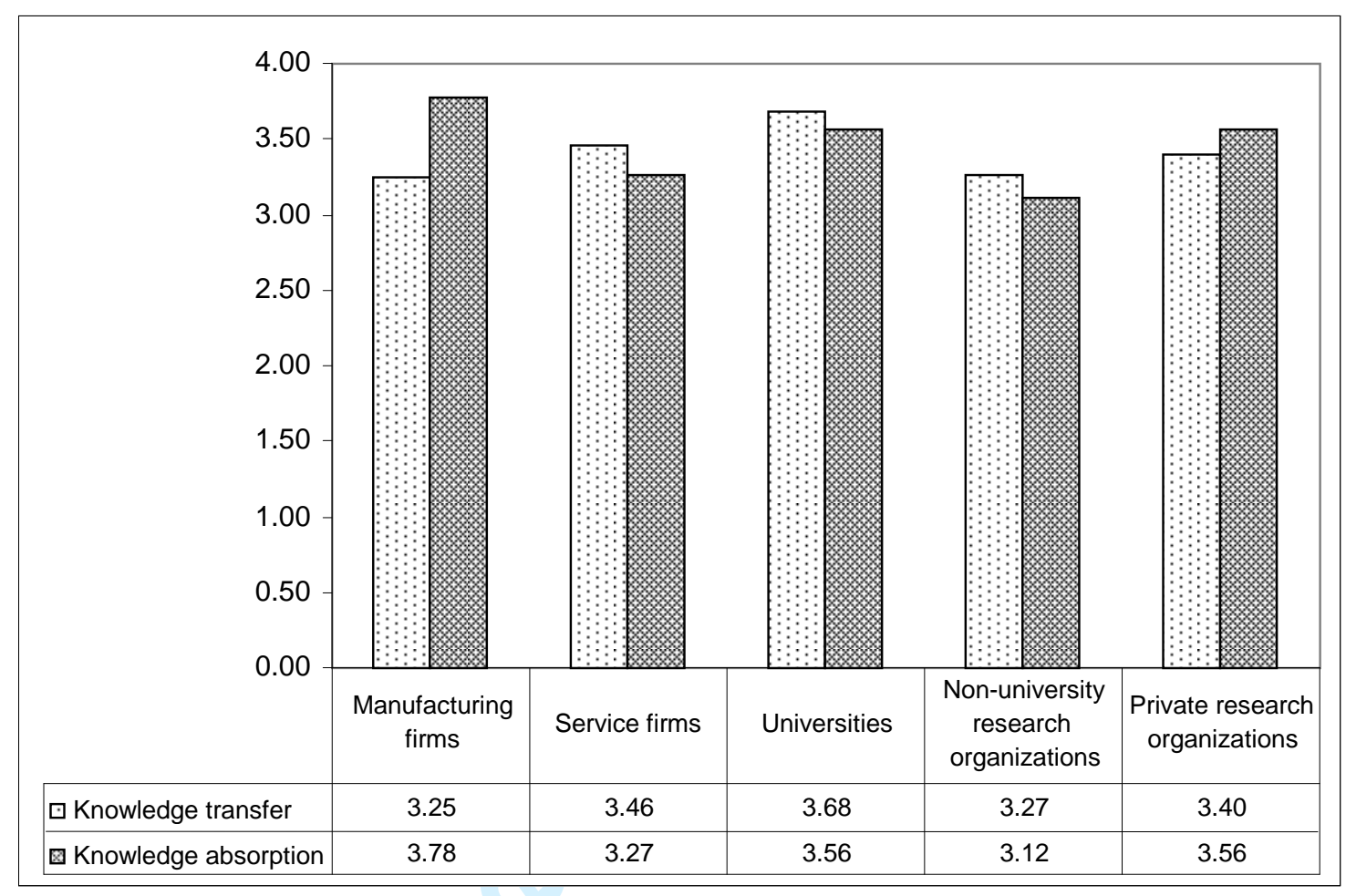

Figure 2: Transfer and absorption of knowledge by organization types 
Nodes $=$ organizations; lines $=$ exchange relations; arrowheads $=$ exchange direction(s); size of symbols $=$ number of broker positions.

Circle/circle in box $=$ manufacturing firms/service firms; up triangle $=$ universities; down triangle $=$ public non-university research organization; other boxes = institutions of basic and advanced training and other.

Figure 3: Number of broker positions 
Figure 4: Inter-regional cooperation activity and knowledge transfer to network partners 


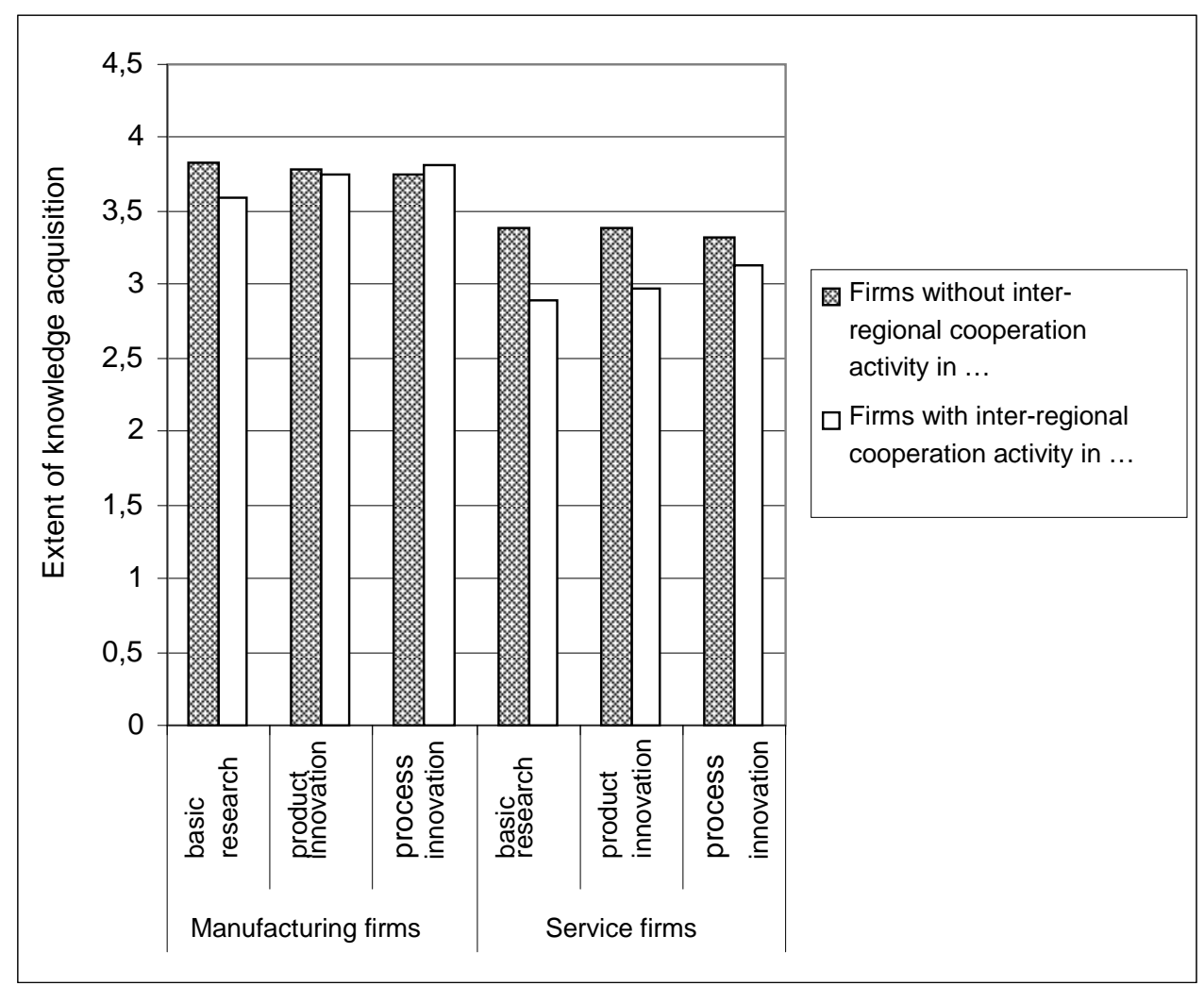

Figure 5: Firms' inter-regional cooperation activity and the extent of knowledge acquired from network partners 